\title{
Framing the Iraq War A Cross-National Comparison of Newspaper Framing in Four Western Countries
}

\section{BY RENS VLIEGENTHART \& HEIKE SCHRÖDER}

In this paper we compare the newspaper attention for and framing of the Iraq issue in four Western countries (US, UK, Germany and the Netherlands) during the period September 2002 until August 2003. Using computer assisted coding based on wordlists constructed by human coders, we analyzed more than 70,000 articles from 12 newspapers. We pose the question how framing differs across countries, time and newspapers. Our results confirm the vast majority of our hypotheses and demonstrate that the national political context, the political leaning of newspapers and the stage of the conflict can account for a large amount of the variation in the attention for the issue and in the way it is presented.

Since World War II, the international community has rarely been as divided as during the 2003 debate on military intervention in Iraq. In the end, a small coalition of allies, led by the United States and the United Kingdom, started the war without UN approval and despite strong opposition from many countries, including Russia, France and Germany.

In this paper, we compare the newspaper coverage of the build up to the Iraq war, the conflict itself and its aftermath in four different Western countries-the United States, the United Kingdom, Germany and the Netherlands. These countries exhibited differences in terms of government policy and public opinion on 
the Iraq invasion. We try to answer the question what causes variation in media coverage of the Iraq war. In order to answer this question we first focus on if and how media coverage differed across time, countries, and news outlets (left-leaning versus right-leaning). Second, we investigate which of those sources of variation contributes most to the explanation of war coverage.

\section{The media on the Iraq war - comparing media coverage}

The coverage of the Iraq war during the first months of 2003 has received considerable attention (e.g. Entman, 2004; Dimitrova and Strömbäck, 2005; Walgrave and Verhulst, 2005). This research, however, has been limited in at least two respects. First, it tends to be restricted to one or two countries (Aday, Livingston and Herbert, 2005; Dimitrova and Strömbäck, 2005; Entman, 2004; Kirstensen and Orsten, 2007; Rutherford, 2004). Second, it tends to be bounded to the period preceding military intervention to the "official" period of war (Aday et al., 2005; Dimitrova and Strömbäck, 2005). The study conducted by Stefaan Walgrave and others (see Walgrave and Verhulst, 2005) is a noteworthy exception. This study was limited, however, to the three months before the actual start of the war. A more complete picture can be obtained by taking into account more countries and a longer research period. We also try to take into account a broader range of possible explanations for observed coverage patterns. The focus is both on the attention that the war received, but also on the way the war is presented - i.e. framed. In that way, our study deals with questions that relate to the coming into existence of media coverage and what is known in communication science as agenda-building (Cobb and Elder, 1971) and frame-building. Both are regarded as important aspects of mass media processes and especially the latter is considered an understudied object (Scheufele and Tewksbury, 2007). 


\section{Media-framing of the Iraq war}

Media coverage can be researched in many ways and numerous aspects of the content of newspaper articles can be taken into account. In this research, we mainly focus on the way the Iraq war is framed. When considering framing in the media, a wide range of classifications and definitions is available. A "classic" definition is the one offered by Entman (1993: 52). He defines media framing as "[selecting] some aspects of perceived reality and make them more salient in a communicating text, in such a way as to promote a particular definition of a problem, causal interpretation, moral evaluation, and/or treatment recommendation for the item described".

Our distinction of frames is based on studies from the field of social movement research and on the media framing of armed conflicts and mainly the work of Snow and Benford (1988). To start with the latter, Snow and Benford (1988) offer a classification distinguishing three core elements of social movement framing: diagnostic framing (problem identification and attributions), prognostic framing (articulation of the proposed solution) and motivational framing (mobilization of collective action). Though Snow and Benford focus in the first instance on social movements, the media themselves can also be one of the actors involved in the framing of movement-issues. Several scholars have researched the media-framing of certain issues (partly) based on this distinction (e.g. Ferree, Gamson, Gerhards and Rucht, 2002; Koopmans and Statham, 1999).

In the study of armed conflicts, several studies employ frames that have a considerable overlap with Snow and Benford's classification (see for example Cooper 2002, Dimitrova and Strömbäck 2005). Snow and Benford's distinction is in line with Entman's definition and offers a good starting point to distinguish frames in a systematic way. The central question in the diagnostic framing task is "what is the problem"? This relates most directly to the (possible) causes or a legitimization to go to war. In the case of prognostic framing, the main question is "what needs to be done"?, which can be relates to the action itself (in this case the intervention in Iraq) as well as the (possible) outcomes, or conse- 
quences, of this action. Snow and Benford's motivational framing encompasses a characteristic of social movement framing ("a call for action") that is less likely to be reflected in media coverage (Snow, Vliegenthart, and Corrigall-Brown, 2007). It is only in rare occasions that media take up a mobilizing role (but see Walgrave and Manssens, 2000). However, the outcome of motivational framing by others can be reported upon. In our specific case the actual protest against the war, is an interesting and distinct characteristic of the media coverage (see also Dimitrova and Strömbäck, 2005).

All in all, this leads us to distinguish four frames:

- Legitimization: the coverage focuses on reasons that do or do not legitimize an intervention in Iraq.

- Intervention: the coverage focuses on plans to go to war or on the intervention and its progression.

- Consequences: the coverage focuses on the possible consequences of the intervention in Iraq.

- Protest: the coverage focuses on protest against or support for the intervention in Iraq.

Next to framing, we also pay attention to the attention and overall tone of the article. This tone can be more or less favorable towards the general issue of military intervention in Iraq by stressing the legitimacy or illegitimacy of the intervention, negative versus positive consequences, and the protest versus support for intervention.

\section{Linking national characteristics, newspaper characteristics and time elements to media content}

To answer our research question on explaining variation in coverage, we focus on the extent to which country, media outlet and time serve as determining factors in differences in this coverage (see also Snow et al., 2007).

\section{Country characteristics}

This government's position is likely to impact media coverage. In a democracy the media ideally reflect the voices expressed by po- 
litical actors of the entire political spectrum-the so-called mirroring function of the media. In Western democracies the media are also expected to "critically observe the political process and concerns of the public and address them to the actors in the political process for processing" (Eilders, 2000: 182), which is known as the watchdog function. Yet the media rely on official sources (Brandenburg, 2002: 39). These actors are deemed important because they occupy positions of power. The media follow the power hierarchy; they pay more attention to government leaders than to ministers, more attention to governing parties than to opposition parties, and so on (Schönbach, de Ridder and Lauf, 2001). While reliance on official sources is economical, it favors their viewpoints at the expense of alternative ones. When media coverage of a given event is reduced to official sources, it is considered to be "indexed." (Bennett, 1990: 106)

The indexing hypothesis would yield the expectation that in countries that are involved directly in the war coverage about it will be more positive. Additionallly, during war times, citizens, but also journalists, refrain from criticizing the government in order not to be regarded as unpatriotic. This rally around the flag is convincingly demonstrated in the United States (Hetherington and Nelson, 2003; see also Ruigrok and Van Atteveldt, 2007).

If we look at the basic assumptions of the indexing hypothesis, also the opposition's point of view is of importance. They can be regarded as official sources that are relatively high in the power hierarchy. If the opposition disagrees with the government's stance, this might partly suppress the positive effect the government's stance has on media coverage. During our research period the US was governed by a Republican president with the Senate and the House of Representatives also dominated by Republicans. Opposition was limited with roughly 40 percent of the Democrats supporting a resolution in Congress that would allow the president to use force. In the UK, the Labor party under the leadership of Tony Blair governed the country. The largest opposition party, the Conservatives, supported military intervention, but the Liberal Democrats and a considerable part of Blair's own party strongly opposed it. In February 2003, almost one third of the Labor faction in parliament voted against war. In Germany, 
Social Democrat leader Gerhard Schröder strongly opposed the war during the 2002 parliamentary election campaign, which helped his government get re-elected. The biggest opposition party, the Christian-Democrats also opposed the intervention, limiting the political support for war. In the Netherlands the political situation was more complicated. Although the Dutch government supported the war politically, opposition came from smaller parties on the left. In the post-election coalition talks between the Christian Democrats, who supported the war, and the Social Democrats, who had a more skeptical attitude, the two parties agreed to support the war politically but not militarily. This attempt at coalition formation ultimately failed and a new coalition, consisting of Christian Democrats and Liberals, was formed that supported the war and sent troops for the rebuilding effort.

A country's participation in the war is likely to not only affect the tone of coverage, but also several other of the media content characteristics we distinguish. Due to the (potential) substantial financial costs for countries involved in the war as well as the casualties it might entail, debate about whether a war is legitimate or not might be more prevalent. Furthermore, the sheer attention for the war might be higher as well. Finally, one might expect that in the country that supports the war initially only politically (Netherlands), but is actively involved in the 'rebuilding' phase more emphasis is put on the consequences of the war.

Also general public opinion might be able to do so. Studies have shown that journalists are in some instances guided by general public opinion and reflect this opinion (Soroka, 2002). According to an international Gallup Poll held in January 2003 public opinion on the issue differed largely ${ }^{1}$, with US citizens being most supportive. This gives us an additional reason to expect coverage in this country to be most favorable. Furthermore, citizens might also get engaged in more explicitly expressing their opinions by participating in protest events. While we include both protests in favor of intervention as well as against intervention, we expect the vast majority of coverage to focus on the latter (see also Dimitrova and Strönbäck 2005). In all of the countries studied, one or several organized coalitions protested against the war (Meyer and Corrigall-Brown, 2005; Walgrave and 
Verhulst, 2003). On February 15, 2003, the largest coordinated demonstrations occurred in the four countries, with the number of estimated participants being 2.5 million (o.9 percent of the population) in the US, one million in the UK (1.6 percent), 500,000 in Germany (0.6 percent), and 70,000 in the Netherlands (0.4 percent) (Walgrave and Verhulst, 2003). Research from the field of social movements has shown that the number of participants is an important predictor for the likelihood that a protest event is covered in the media (Smith et al., 2001). It seems reasonable to extend this argument and expect the incidence of the protest frame to increase with the size of protest events. This size might be a good proxy for the level of mobilization against the war that is present within a society and thus for the wider dissemination of protest beyond this single event. The more well-attended protest events take place, the more media will report about it. This results in the expectation that in the US and the UK media protest framing will occur most often.

Overall, the country-level differences result in the following six hypotheses: ${ }^{2}$

(H1a) In countries whose governments supported the war (UK, US and Netherlands), the war reporting is more positive.

(H1b) In countries where little formal political opposition to the government's formal position exists (US, Germany and Netherlands), the tone of reporting is more in line with the government's formal position.

(H1c) In countries that are support the war militarily (UK and US) the legitimization framing is used more often.

(H1d) In countries that support the war militarily (UK and US), more attention will be paid to the Iraq issue.

(H1e) In the country that is solely involved in the rebuilding effort (Netherlands), more emphasis will be put on the (potential) consequences of the war.

(Hif) In countries where protest events against the war are largest (UK and US), the protest frame is used more often.

\section{Newspaper characteristics}

Media coverage could also be affected by newspaper characteristics, particularly their political orientation and partisan leaning. 
Newspapers can be classified as positioned on the left, in the center or on the right of the political spectrum (Kleinnijenhuis, 2003). Regarding the political orientation of the newspapers, we expect a straightforward relationship: the more leftist the newspaper, the more negative it will be about intervention, reflecting the general political position of left-wing politicians and citizens (Walgrave and Verhulst, 2005). Furthermore, since protest against the war was concentrated on the left side of the political spectrum, leftist newspapers are more likely to pay attention to protests and protest framing. This results in the following two hypotheses:

(H2a) The more leftist the newspaper, the less favorable media coverage about the war will be.

(H2b) Leftist newspapers will use the protest frame more often than other newspapers.

\section{Time aspects/factors}

As a certain event or issue advances, there can be considerable shifts in the way the issue is presented. We take into consideration whether news coverage occurs in the period before, during or after the "official" war. Our expectations regarding the time periods are rather straightforward and based on the assumption that mass media coverage reflects the actual stage of the conflict. We expect that in the months preceding the war, when the debate was focusing on whether or not to invade, the news will focus on the question whether the war is legitimate. Furthermore, during that period most protest events took place, resulting in the expectation that protest framing is more present during that time. During the war itself, coverage will shift to the intervention. Additionally, due to the newsworthiness of actual war activity it is likely that attention is higher compared to before and after the war. After the war, when the real effects of this war become more apparent, we expect more media attention for the consequences of the war. This results in the following hypotheses:

(Hзa) Legitimization framing is most present in the months preceding the war.

(H3b) Protest framing is most present in the months preceding the war. 
(H3c) Intervention framing is most present during the official war.

(H3d) Attention is highest during the official war.

(Hзe) Consequences framing is most present after the official war.

\section{Methods}

Our research period ranges from the beginning of September 2002 until the end of August 2003, covering several months before the March 2003 intervention, as well as the intervention itself and several months after the official end of the war in April 2003. As mentioned, we investigated four countries that differ considerably on the key independent variables of interest: the United Kingdom, the United States, Germany and the Netherlands.

Our independent variables indicating the political context are operationalized as follows:

Political leaning of newspaper. We selected three newspapers from each country, making a distinction between "leftist", "center" and "rightist" newspapers. In the analysis, we included dummies for left-leaning and right-leaning newspapers. For each country we selected three newspapers, which differ in their leftright positioning (Eilders, 2002; Kleinnijenhuis, 2003; Walgrave and Verhulst, 2005). They are presented in Table $1 .{ }^{3}$

Finally, here is how we operationalized the stage of the conflict:

\section{Table 1}

Newspapers and their left-right positioning per country

\begin{tabular}{llll}
\hline & Left & Center & Right \\
\hline United States & Washington Post & New York Times & USA Today \\
\hline United Kingdom & Guardian & Independent* $^{*}$ & The Times* $^{*}$ \\
\hline Germany & Tageszeitung & Süddeutsche & Frankfurter \\
& & Zeitung & $\begin{array}{l}\text { Allgemeine } \\
\text { Zeitung }\end{array}$ \\
\hline Netherlands & Volkskrant & NRC Handelsblad & Telegraaf \\
\hline
\end{tabular}

Note: ${ }^{*}$ Sunday editions are included 
Time aspects. We capture time-differences by dividing our research period into three phases. The first phase lasts from September 2002 until the beginning of the war on March 20, 2003. The second phase covers the official war period, which lasted from March $20^{\text {th }}$ until April 10, the day that the statue of Saddam Hussein was taken down in Baghdad and officials declared the war to be over. The third phase, the post-war period, covers the remaining weeks of our study: April 11 through August 31, 2003. In the analysis, we included dummies for the pre-war and war periods.

\section{Media Framing}

We now turn to the operationalization of our dependent variables.

We searched the selected newspapers for all articles containing the word "Iraq" (US and UK newspapers) or "Irak" (German and Dutch newspapers) in LexisNexis. In total we retrieved 70.490 articles. We acknowledge that not all of the articles are of equal importance in their content and placement. To cover some of this variation we weighted front-page articles twice as heavily as the other articles. This way, our final sample contained 85.474 units of analysis (see Table 2), with considerable cross-country differences regarding both the number and length of articles.

Various news frames. The occurrence of each media frame per article was established using computer assisted coding. Frames were distinguished using word combinations (search strings) indicative of the presence of a given frame (Gamson and Mogdiliani, 1989).

The search-strings were derived by coding a random sample of 100 articles per country. For each article, a coder identified the frames and what words or word combinations were associated with each frame. A score of o ("frame not present") or 1 ("frame present") was assigned. The same was done for the tone-variable (-1 non-favorable; o neutral/mixed; 1 favorable). Based on the indicated word(s) and word-combinations for each country, extensive search-strings were composed (see Appendix A for the Englis version). The coder also noted whether an article included favorable and non-favorable tone elements. 


\section{Table 2}

Background characteristics of newspaper coverage per country

\begin{tabular}{lccc}
\hline & $\begin{array}{c}\text { Number of } \\
\text { articles }\end{array}$ & $\begin{array}{c}\text { Mean article } \\
\text { length (words) }\end{array}$ & $\begin{array}{c}\text { Mean number of } \\
\text { frames per article }\end{array}$ \\
\hline United States & 28207 & 861 & 1.08 \\
\hline United Kingdom & 26351 & 628 & 0.93 \\
\hline Germany & 19908 & 3781 & 0.89 \\
\hline Netherlands & 11008 & 557 & 0.70 \\
\hline Total & 85474 & 613 & 0.94 \\
\hline
\end{tabular}

Note: Number of articles is weighted score, with the ones appearing on front page counting twice; ${ }^{1}$ the mean length for Germany is lower than for the other countries, partly due to the fact that for some articles only the headline was recorded in LexisNexis. Excluding those articles indeed results in a mean article length of over 400 words $(\mathrm{N}=18,465)$, as well as an increase in the mean number of frames per article to 0.94 . Since it is not possible to extract frames from just the headline, those articles are excluded from further analyses that relate to framing.

To establish the reliability of our wordlists, we took another random sample, this time of 145 articles. A second coder coded these articles and the results were compared with the results of the coding done by computer using the wordlists. We used two measures from information science to test the quality of our wordlists against the "golden standard" of the manually coded sample. These are precision and recall (Voorhees, 2004: 4). Precision refers to the percentage of times the computer accurately assigned a category, i.e. of all articles that contain a certain frame according to the computer, which part does indeed contain this frame? The recall measure is the proportion of cases in the category that was predicted, i.e. of all articles that contain a certain frame, what part does the computer recognize? Generally, precision can be increased at a cost of recall and vice versa. Precision for each of our framing-elements .61 and tone was on average and recall .64. For tone, disregarding the articles that the computer assigned to the neutral/mixed category, precision is .53 and recall .67.

While the scores might be considered as somewhat low when using traditional standards for inter-coder agreement, we regard 
them as satisfactory, taking into account the problems computer-assisted coding has in determining the semantic meaning of texts (Roberts, 2000). We tested for and found no systematic differences between the overall outcomes of the manual coding and the computer-assisted one. It is therefore reasonable to assume that on an aggregate level - on which most of the analyses are based - errors level each other out.

\section{Method of analysis}

Our analyses include tests for differences between countries and newspapers for attention, frames and tone. To test more precisely the influence of our country, newspaper and time variables on the use of various frames, we used each combination of countries (4), newspaper (3 within each country) and period (3) as our unit of analysis. This results in a total number of observations of 36 .

For each unit of analysis, we calculated the daily average attention for the issue and for each of our frames the proportional use for each newspaper in each time period. Similarly, we calculated the overall mean of the favorability-variable (direction). To assess (the size of) the influence of each of our independent variables (country, newspaper, time), we use General Linear Modeling (GLM). This is a multivariate analysis of variance, in which the relative influence of each independent variable is estimated. Additionally, it converses our nominal variables into a set of dummies. The effect sizes for these dummies indicate whether and how certain categories (i.e. countries) differ from each other. Though observations are not independent - they are clustered in time, country and type of newspaper - treating exactly those three criteria as independent variables offers the opportunity to assess how and to what extent variation in our media variables can be attributed to time, country and newspaper (see Snow et al., 2007 for a similar analytical strategy).

\section{Results}

Figure 1 presents media attention to the Iraq issue over time in weighted numbers of articles per country.

Since the main part of the attention is determined by interna- 


\section{Figure 1}

Attention for the Iraq-issue in four countries

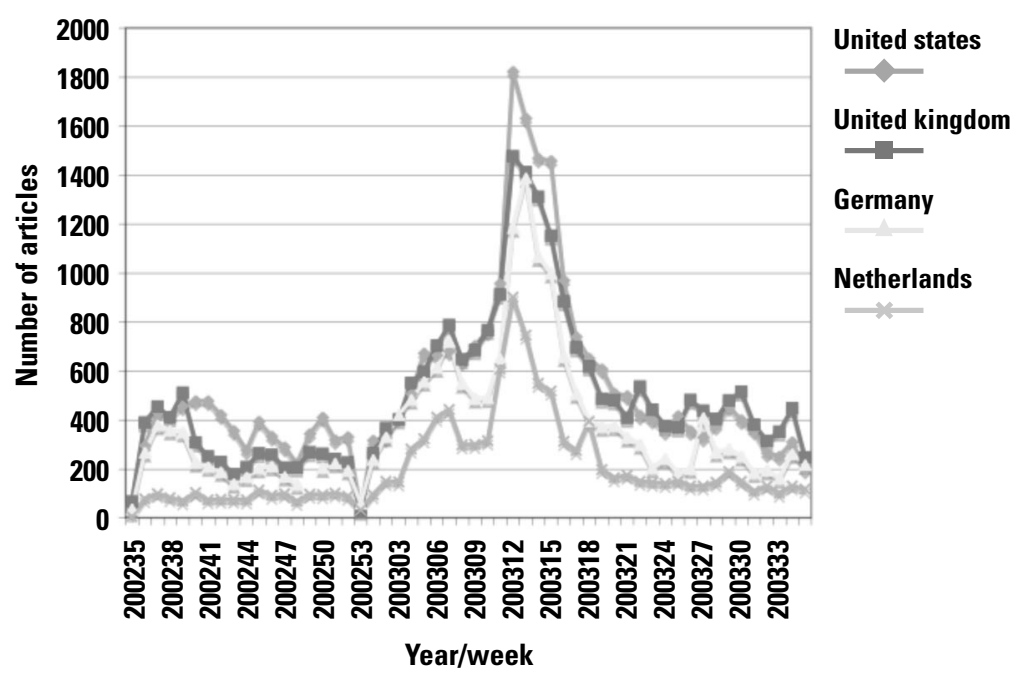

Note: Number of articles is a weighted score, with articles appearing on front page counting twice.

tional events, it is hardly surprising that the level of media attention in all four countries follows largely the same pattern. The correlations between the weekly attention in each country range from .93 to .96. Absolute peaks were reached in March 2003, when the military intervention took place.

We now turn to a cross-national comparison of the use of the various frames and tone. Table 3 displays the comparison of media variables and therefore the test of our hypotheses. We will discuss the dependent variables one by one and specifically refer to the hypotheses as formulated in theory section.

\section{Attention}

With regard to attention paid to the issue, we expected differences across countries and time. We expected that in the US and the UK, the countries that got really involved in the war, attention would be larger (hypothesis 1d). The analysis confirms this hypothesis. There exist significant differences across countries $(F-$ test $=4.251, \mathrm{p}<.05)$ and indeed, in the UK and US the daily ave- 
Table 3

Explaining differences in media coverage of the Iraq war

\begin{tabular}{|c|c|c|c|c|c|c|}
\hline & Attention & $\begin{array}{l}\text { Legiti- } \\
\text { mization }\end{array}$ & $\begin{array}{c}\text { Inter- } \\
\text { vention }\end{array}$ & $\begin{array}{c}\text { Conse- } \\
\text { quences }\end{array}$ & Protest & Tone \\
\hline Constant & $\begin{array}{c}.209 \\
(6.309)\end{array}$ & $\begin{array}{c}.229^{* * *} \\
(.018)\end{array}$ & $\begin{array}{c}.128^{* * *} \\
(.014)\end{array}$ & $\begin{array}{c}.224^{* * *} \\
(.013)\end{array}$ & $\begin{array}{l}-.013 \\
(.013)\end{array}$ & $\begin{array}{l}-.017 \\
(.015)\end{array}$ \\
\hline $\begin{array}{l}\text { Coun- } \\
\text { tries } \\
\text { (F-test) }\end{array}$ & $4.251^{* *}$ & $7.017^{* * *}$ & $39.828^{* * *}$ & $9.733^{* * *}$ & $41.695^{* * *}$ & $21.633^{* * *}$ \\
\hline $\begin{array}{l}\text { United } \\
\text { Kingdom }\end{array}$ & $\begin{array}{c}17.659 * * * \\
(6.309)\end{array}$ & $\begin{array}{l}.040^{* *} \\
(.018)\end{array}$ & $\begin{array}{c}.112^{* * *} \\
(.014)\end{array}$ & $\begin{array}{c}-.011 \\
(.013)\end{array}$ & $\begin{array}{c}.103^{* * *} \\
(.013)\end{array}$ & $\begin{array}{c}-.078^{* * *} \\
(.015)\end{array}$ \\
\hline $\begin{array}{l}\text { United } \\
\text { States }\end{array}$ & $\begin{array}{c}20.614^{* * *} \\
(6.309)\end{array}$ & $\begin{array}{c}.074^{* * *} \\
(.018)\end{array}$ & $\begin{array}{c}.145^{* * *} \\
(.014)\end{array}$ & $\begin{array}{l}.028 * * \\
(.013)\end{array}$ & $\begin{array}{c}.130^{* * * *} \\
(.013)\end{array}$ & $\begin{array}{c}-.076^{* * *} \\
(.015)\end{array}$ \\
\hline Germany & $\begin{array}{l}10.614 \\
(6.309)\end{array}$ & $\begin{array}{c}.006 \\
(.018)\end{array}$ & $\begin{array}{c}.096^{* * *} \\
(.014)\end{array}$ & $\begin{array}{c}.050^{* * *} \\
(.013)\end{array}$ & $\begin{array}{c}.118^{* * * *} \\
(.013)\end{array}$ & $\begin{array}{c}-.115^{* * *} \\
(.015)\end{array}$ \\
\hline $\begin{array}{l}\text { News } \\
\text { papers } \\
\text { (F-test) }\end{array}$ & 1.410 & .403 & $2.407^{*}$ & .500 & $6.583^{* * *}$ & $5.023^{* *}$ \\
\hline Leftist & $\begin{array}{c}-.110 \\
(5.463)\end{array}$ & $\begin{array}{c}.007 \\
(.016)\end{array}$ & $\begin{array}{l}.026^{* *} \\
(.012)\end{array}$ & $\begin{array}{c}.009 \\
(.011)\end{array}$ & $\begin{array}{c}.036^{* * *} \\
(.011)\end{array}$ & $\begin{array}{c}-.040^{* *} \\
(.013)\end{array}$ \\
\hline Center & $\begin{array}{c}7.891 \\
(5.463)\end{array}$ & $\begin{array}{l}-.007 \\
(.016)\end{array}$ & $\begin{array}{c}.013 \\
(.012)\end{array}$ & $\begin{array}{c}.010 \\
(.011)\end{array}$ & $\begin{array}{c}.001 \\
(.011)\end{array}$ & $\begin{array}{l}-.024^{*} \\
(.013)\end{array}$ \\
\hline $\begin{array}{l}\text { Time } \\
\text { (F-test) }\end{array}$ & $21.218^{* * *}$ & $21.574^{* * *}$ & $42.593^{* * *}$ & $27.785^{* * *}$ & $19.462^{* * *}$ & $5.490^{* *}$ \\
\hline Before & $\begin{array}{c}1.376 \\
(5.463)\end{array}$ & $\begin{array}{c}.055^{* * *} \\
(.016)\end{array}$ & $\begin{array}{c}.096^{* * *} \\
(.012)\end{array}$ & $\begin{array}{c}-.081^{* * *} \\
(.011)\end{array}$ & $\begin{array}{c}.065^{* * *} \\
(.011)\end{array}$ & $\begin{array}{l}-.007 \\
(.013)\end{array}$ \\
\hline During & $\begin{array}{c}31.488^{* * *} \\
(5.463)\end{array}$ & $\begin{array}{c}-.049 * * * \\
(.016)\end{array}$ & $\begin{array}{c}.097^{* * *} \\
(.012)\end{array}$ & $\begin{array}{c}-.032^{* * *} \\
(.011)\end{array}$ & $\begin{array}{c}.056^{* * * *} \\
(.011)\end{array}$ & $\begin{array}{c}-.039 * * * \\
(.013)\end{array}$ \\
\hline $\begin{array}{l}\text { F-test } \\
\text { total } \\
\text { model }\end{array}$ & $8.287^{* * *}$ & $9.286^{* * *}$ & $29.926^{* * *}$ & $12.253^{* * *}$ & $25.311^{* * *}$ & $12.275^{* * *}$ \\
\hline $\begin{array}{l}\text { Adjusted } \\
R- \\
\text { squared }\end{array}$ & .674 & .624 & .853 & .692 & .829 & .693 \\
\hline
\end{tabular}

Note: Between parentheses are unstandardized coefficients from GLM-analyses, where for independent variable various categories are included as dummies (reference categories are the Netherlands (countries); Rightist (newspapers); After (Time)); $\mathrm{N}=36 .{ }^{* *} \mathrm{p}<.01 ;{ }^{* *} \mathrm{p}<.05 ;{ }^{*} \mathrm{p}<.10$ (two-tailed tests). 
rage number of articles (weighed) is significantly higher than in our reference category (the Netherlands). This difference is large: British newspapers publish on average almost 18 more articles per day, while for US newspapers this is even more than 20. Also German newspapers publish more articles than Dutch newspapers, but this difference is not significant. Furthermore, we hypothesized that during the war, attention would be highest (hypothesis 3d). This hypothesis is confirmed by the analysis as well: differences across time stages are significant $(F$-test $=21.218$; $\mathrm{p}<.01$ ) and during the official war period, on a daily basis, more than 31 more articles were published than after the war. The period before the war does not significantly differ from the period after the war. We do not find any significant differences across newspapers. Overall, our model explains a considerable amount of the variation in attention (adjusted R-squared $=.674$ ).

\section{Legitimization framing}

We expected the use of the legitimization frame to differ across countries and time periods as well. First, we expected the legitimization discussion to be more prevalent in countries that were involved militarily in the war (hypothesis 1a). Again, the hypothesis is supported by the data. Differences across countries are significant. In the United Kingdom the legitimization frame is used in an additional 4 percent of the articles and in the United States even in an additional 7.4 percent. Germany does not differ from the Netherlands. The difference across time is significant as well and hypothesis 3 a is confirmed: before the war the legitimization frame is used in an additional 5.5 percent of the articles compared to the after war-period. Interestingly, the frame is used less often during the war. Apparently, the debate about where the war was justified re-intensified after major combat ended and, for example, no weapons of mass destruction were found. Again, with an adjusted R-squared of .624, we explain a considerable amount of variance in legitimization framing.

\section{Intervention framing}

When it comes to the use of the intervention frame, we again expected differences across countries and time. We expected that 
the actual war was most often reported in the countries that were involved militarily (hypothesis 1c). This hypothesis is confirmed by our data: differences across countries are significant and both British and US newspapers make use of the intervention frame more often (in an additional 11.2 and 14.5 percent of the articles compared to the Netherlands). Furthermore, we find Germany to differ significantly from the Netherlands as well. Also here, the intervention itself is more often discussed, though less than in the UK and the US (in 9.6 percent more articles). With regard to time, we hypothesized the intervention frame to be most prevalent during the official war itself (hypothesis 3c). This hypothesis is partly confirmed by our analysis: again, there exist significant differences across time. The frame is used more often than after the war (in an additional 9.7 percent of the articles), but the difference in use before and during the war is marginal and insignificant. Apparently, already in the build-up phase reporting about possible war activities was widely present. Additionally, newspapers differ somewhat in their use of the intervention frame. Leftist newspapers use slightly more often the intervention frame than rightist newspapers (in an additional 2.4 percent of the articles), but this difference is very small, especially compared to the differences across countries and time. Our model captures differences in intervention framing really well (adjusted R-squared $.853)$.

\section{Consequences}

We now turn to the use of the consequences frame. Again, we hypothesized differences across countries and over time. First, we expected consequences framing to be most prevalent in the country that was only involved in the rebuilding phase, the Netherlands (hypothesis 1e). Our data do not provide support for this hypothesis. While there exist cross-national differences, only the United Kingdom reports less about the consequences than the Netherlands, but this difference is not significant. Especially in Germany, the consequences are widely discussed. Apparently, the country that did not want to get involved in the war discusses the (potentially harmful) consequences of this war most often. The hypothesis with regard to the different stages of the conflict 
(hypothesis 3e) is confirmed: consequences framing is most often used after the war. Additionally, we find an overall increase in use of this frame: it is less often used before the war and somewhat more during the war. Again, we find no differences across newspapers and our model explains a considerable amount of variance (69.2\%).

\section{Protest}

The last frame we discuss is the protest frame. We hypothesized it to be more present in countries with considerable mobilization against the war (hypothesis if), in leftist newspaper (hypothesis 2b) and before the war (hypothesis $3 b$ ). Our results partly confirm hypothesis if and support hypothesis $2 \mathrm{~b}$ and hypothesis $3 \mathrm{~b}$. First, differences across countries are significant. Indeed, protest coverage is the least present in the country with relatively weak protest (the Netherlands); in all other countries the protest frame occurs in between 10 and 13 percent additional articles. However, protest framing is most prevalent in the United States, where in absolute terms most demonstrators attended the large February demonstration, but the country with relatively the most attendants - the UK - scores even lower than Germany. Second, also differences across newspapers are significant and in line with the expectations: the protest frame is used more often in leftist newspapers compared to center and rightist newspapers. Third, the protest frame is used most often before the war, though it is also still present during the war. Our model again explains a considerable amount of variance $(82.9 \%)$.

\section{Tone}

The final analysis involves the tone towards the war. Overall, the tone is somewhat negative, but there is considerable variation across countries and time (see Figure 2). Here, we first hypothesized that in countries where the government supported the war, the reporting would be more positive (hypothesis 1a) and that little formal opposition would result in reporting more in line with the government's position (hypothesis $1 b$ ). The analysis confirms hypothesis 1a and largely confirms hypothesis $1 \mathrm{~b}$. Overall, German newspapers are most negative in their tone towards the 


\section{Figure 2}

Mean monthly tone of coverage of the Iraq-issue in four countries

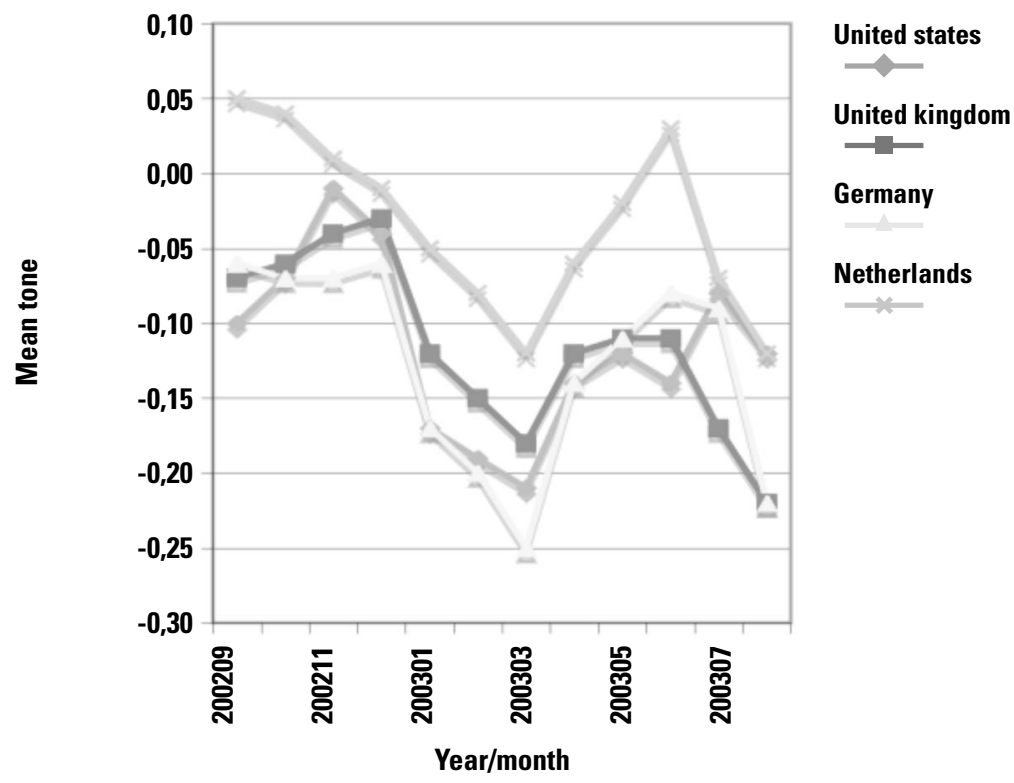

war. Interestingly enough, the difference between the Netherlands and the other countries is again the largest one: Dutch newspapers report considerable more positive about the war. We will get back to this finding in the conclusion. The UK and the US take a middle position. Furthermore, we expected the United Kingdom to differ from the other countries due to considerable opposition to the formal government position. Compared to the US and the Netherlands, the coverage is indeed slightly more negative, confirming hypothesis $\mathrm{lb}$. We have to admit, however, that the difference with the US newspapers is very small. With regard to newspaper differences, we expected that the more leftist the newspaper is, the less favorable media coverage about the war would be. Though differences across newspapers are small, they are perfectly in line with our expectations. Leftist newspapers report the least favorable about the war (.040 lower score on the -1 to +1 scale compared to rightist newspapers), followed by center newspapers (.024 lower). During the war, the tone was less favorable, probably because most coverage about casualties was 
present during that period. Our model explains almost $70 \%$ of the variance in tone.

\section{Conclusion and discussion}

Our analyses show important and fascinating variation in the newspaper coverage of the Iraq-issue in the countries, time periods and newspapers under study. Table 4 summarizes our results on the basis of the hypotheses we formulated in the theory section. To a considerable extent, we were able to explain differences in media coverage by looking at the countries' political contexts, characteristics of the newspapers and the stage of the conflict. The vast majority of our hypotheses is supported by the data.

Explaining differences in coverage in substantial terms is not an easy task, since numerous factors might account for the amount, framing and tone of coverage. Our paper is a first attempt to disentangle some of those factors and while our results largely confirm the presupposed impact of time period, the national political context and newspaper leaning, for some of the findings other case-specific explanations are plausible. The most noteworthy - and largely unexplained - result is the coverage in the Netherlands. Two explanations may be offered for the comparatively low and favorable coverage in this country. On the one hand this may be due to the fact that in contrast to the US and the UK (the two main leaders of the Iraq war) and Germany (one of the leading opposition forces) the Dutch government played a much less central role in both the event itself and the international debate surrounding it. On the other hand, the national debate was overshadowed by an election campaign in which the Iraq issue played some part but which was dominated by domestic issues. The combination of those two factors is likely to have caused the Iraq issue to be less salient and less controversial in the Dutch media as compared to the other three countries. Remarkably enough, Nord and Strömbäck (2006) find similar results for Sweden, a country that in terms of its international position is very comparable to the Netherlands. They take a critical stance towards the journalists in this country and one can ques- 


\section{Table 4}

Summary of results

\begin{tabular}{|c|c|}
\hline Hypothesis & Result \\
\hline \multicolumn{2}{|l|}{ Country differences } \\
\hline $\begin{array}{l}\text { 1a. In countries whose governments supported the war (UK, } \\
\text { US and Netherlands), the war reporting is more positive. }\end{array}$ & + \\
\hline $\begin{array}{l}\text { 1b. In countries where little formal political opposition to the } \\
\text { government's formal position exists (US, Germany and } \\
\text { Netherlands), the tone of reporting is more in line with } \\
\text { the government's formal position. }\end{array}$ & + \\
\hline $\begin{array}{l}\text { 1c. In countries that are actively fully support the war (UK } \\
\text { and US) the legitimization framing is used more often. }\end{array}$ & + \\
\hline $\begin{array}{l}\text { 1d. In countries that fully support the war (UK and US), more } \\
\text { attention will be paid to the Iraq issue. }\end{array}$ & + \\
\hline $\begin{array}{l}\text { 1e. In the country that is solely involved in the rebuilding } \\
\text { effort (Netherlands), more emphasis will be put on the } \\
\text { (potential) consequences of the war. }\end{array}$ & - \\
\hline $\begin{array}{l}\text { 1f. In countries where protest events against the war are } \\
\text { largest (UK and US), the protest frame is used more often. }\end{array}$ & $+/-$ \\
\hline \multicolumn{2}{|l|}{ Newspaper differences } \\
\hline $\begin{array}{l}\text { 2a. The more leftist the newspaper, the less favorable } \\
\text { media coverage about the war will be. }\end{array}$ & + \\
\hline $\begin{array}{l}\text { 2b. Leftist newspapers will use the protest frame more } \\
\text { often than other newspapers. }\end{array}$ & + \\
\hline \multicolumn{2}{|l|}{ Time differences } \\
\hline $\begin{array}{l}\text { 3a. Legitimization framing is most present in the months } \\
\text { preceding the war. }\end{array}$ & + \\
\hline $\begin{array}{l}\text { 3b. Protest framing is most present in the months } \\
\text { preceding the war. }\end{array}$ & + \\
\hline $\begin{array}{l}\text { 3c. Intervention framing is most present during the } \\
\text { official war. }\end{array}$ & + \\
\hline 3d. Attention is highest during the official war. & + \\
\hline $\begin{array}{l}\text { 3e. Consequences framing is most present after } \\
\text { the official war. }\end{array}$ & + \\
\hline
\end{tabular}


tion whether this indeed offers a good explanation for the crossnational differences between Swedish (or Dutch) coverage and for example German coverage. However, cross-national differences in journalistic practices and norms towards war coverage might be an important factor to consider in future research.

For scholars who have an interest in comparative media research this study offers some interesting insights. One of them is that it is not sufficient to only look at countries and/or newspapers. Whether one studies the coverage of election campaigns, contentious politics, issue-coverage during routine times or - as we did - international conflicts, one cannot neglect the inherent, time-specific dynamics surrounding political issues, not only in attention (for example issue-attention cycles, Downs, 1957), but also in terms of how the issue is covered. The recent study on the Iraq coverage in Danish press by Kristensen and Orsten (2007) also shows the important over-time fluctuation in content characteristics. Finally, our paper shows the increasing possibilities of the use of computer assisted coding of media content and other texts. While the approach of manually constructing wordlists based on a sample of the texts and consequently using the computer to analyze the very largest part of the articles needs to be optimized and higher reliability needs to be obtained, we believe that this research nonetheless demonstrates its usefulness and the findings it yields.

\section{NOTES}

1. We are aware of the fact that public opinion does not only differ substantially across countries, but fluctuates heavily over time as well. Unfortunately, comparable over-time data for all four countries are not available, so we have to stick to this cross-national comparative measure.

2. Another important country characteristic that is often used to explain (political) news coverage is the media system to which it belongs (Hallin and Mancini, 2004). We have refrained from including this here, because it is hard to theorize how this macro-level and abstract characteristic would influence the specific elements of war co- 
verage that we distinguish. Furthermore, based on Hallin and Mancini, we would divide the countries in Liberal ones (UK and US) and continental ones (Germany and Netherlands). This division overlaps completely with the distinction made between countries that support and do not support the war, which we deem a theoretically more relevant variable.

3. One could argue about whether that the classification of the US newspapers is correct. It is hard to classify those three newspapers in a left-right order, but since these are the three main national newspapers we decided to include them in the analysis and follow Walgrave \& Verhulst's (2005) left-right classification. Furthermore, we tested in additional analyses whether the results for the US newspapers were different from the other newspapers. In all instances, no significant differences were found.

\section{REFEREN CES}

Aday, S., S. Livingston and M. Hebert. 2005. "Embedding the Truth. A Cross-Cultural Analysis of Objectivity and Television Coverage of the Iraq War", Harvard International Journal of Press/Politics, 10(1), 3-21.

Bennett, L. 1990. “Toward a Theory of Press-State Relations in the United States", Journal of Communication, 40(2), 103-125.

Bennett, L. and D. Paletz, eds 1994. Taken by the Storm. The Media, Public Opinion and US Foreign Policy. Chicago: University of Chicago Press.

Brandenburg, H. 2002. "Who follows whom?: The Impact of Parties on Media Agenda Formation in the 1997 British General Election Campaign”, Press/Politics, 7(3), 34-54.

Cooper, A.H. 2002. "Media Framing and Social Movement Mobilization: German Peace Protest Against INF Missiles, the Gulf War and NATO Peace Enforcement in Bosnia”, European Journal of Political Research, 41(1), 37-80.

Cobb, R.W., and D.W. Elder. 1971. "The Politics of Agenda-Building. An Alternative Perspective for Modern Democratic Theory”, Journal of Politics, 33(4), 892-915.

Dimitrova, D.V. and J. Strömbäck. 2005. "Mission Accomplished? Framing of the Iraq War in the Elite Newspapers in Sweden and the United States", Gazette, 67(5), 399-417.

Eilders, C. 2000. "Media as Political Actors? Issue Focusing and Selective 
Emphasis in the German Quality Press", German Politics, 9(3), 181206.

Eilders, C. 2002. "Conflict and Consonance in Media Opinion: Political Positions of Five German Quality Newspapers”, European Journal of Communication, 17(1), 25-63.

Entman, R.M. 1993. "Framing: Toward clarification of a fractured paradigm”, Journal of Communication, 43(4), 51-58.

Entman, R.M. 2004. Projections of Power. Framing News, Public Opinion, and US Foreign Policy. Chicago: University of Chicago Press.

Esser, F. and P. D’ Angelo. 2006. “Framing the Press and Publicity Process in US, British, and German General Election Campaigns. A Comparative Study of Metacoverage", Harvard International Journal of Press/Politics, 11(3): 44-66.

Esser, F. and B. Pfetsch 2004. Comparing Political Communication. Theories, Cases and Challenges.

Ferree, M.M., W.A. Gamson, J. Gerhards and D. Rucht 2002. Shaping Abortion Discourse. Cambridge: Cambridge University Press.

Gamson, W.A. and A. Modigliani 1989. "Media discourse and public opinion on nuclear power: A constructionist approach", American Journal of Sociology, 95(1), 1-37.

Gans, H. J. 1979. Deciding what's news. A study of CBS evening news, NBC Nightly News, Newsweek and Time. New York: Pantheon Books

Hallin, D. C. and P. Mancini. 2004. Comparing Media Systems. Three Models of Media and Politics. Cambridge: Cambridge University Press.

Hetherington, M., and M. Nelson. 2003. "Anatomy of a Rally Effect: George W. Bush and the War on Terrorism", PS: Political Science and Politics, 36, 37-42.

Kriesi, H., R. Koopmans, J.W. Duyvendak and M. Giungi. 1995. New Social Movements in Western Europe. A Comparative Analysis. Minnesota: University of Minnesota Press.

Kristensen, N. N. and M. Orsten (2007). "Danish media at war: The Danish media coverage of the invasion of Iraq in 2003”, Journalism 8(3), 323-343.

Kleinnijenhuis, J. 2003. "Het Publiek Volgt Media die de Politiek Volgen”. Pp. 151-212 in Medialogica RaadVoor Maatschappelijke Ontwikkeling. Den Haag: SDU Uitgevers.

Koopmans, R. and P. Statham. 1999. "Challenging the Liberal Nation 
State? Postnationalism, Multiculturalism, and the Collective Claims Making of Migrants and Ethnic Minorities in Britain and Germany", American Journal of Sociology, 105(3): 652-696.

Meyer, D.S. and C. Corrigall-Brown. 2005. "Coalitions and Political Contexts. US Movements against Wars in Iraq", Mobilization: An International Journal, 10(3): 327-344.

Nord, L. W. and J. Stromback. 2006. "Reporting More, Informing Less: A Comparison of the Swedish Media Coverage of September 11 and the Wars in Afghanistan and Iraq", Journalism, 7(1), 85-110.

Pan, Z. and G. M. Kosicki. 1993. "Framing analysis: An approach to news Discourse”, Political Communication, 10(1), 55-75.

Roberts, C.W. 200o. "A Conceptual Framework of Quantitative Text Analysis", Quality and Quantity, 34(3), 259-274.

Ruigrok, P.C., and W.A. van Atteveldt. 2007. "Global Angling with a Local Angle: How US, British, and Dutch Newspapers Frame Global and Local Terrorist Attacks", Harvard International Journal of Press/Politics, 12(1), 68-90.

Scheufele, D.A., and D. Tewksbury. 2007. "Framing, Agenda Setting, Priming: The Evolution of Three Media Effects Models”, Journal of Communication, 49(4), 103-122.

Schönbach, K., Ridder, J. de and E. Lauf. 2001. "Politicians on the News: Getting Attention in Dutch and German Election Campaigns”, European Journal of Political Research, 39(4), 519-531.

Shah, D.V., M.D. Watts, D. Domke and D.P. Fan. 2002. "News framing and cueing of issue regimes: explaining Clintons' s public approval in spite of scandal”, Public Opinion Quarterly, 66(3), 339-370.

Smith, J., J. McCarthy, C. McPhail and B. Augustyn. 2001. "From Protest to Agenda Building: Description Bias in Media Coverage of protest Events in Washington D.C. ”, Social Forces, 79(4), 1397-1423.

Snow, D.A., and R.D. Benford. 1988. "Ideology, Frame Resonance, and Participant Mobilization” International Social Movement Research, 1, 197-217.

Snow, D.A., R. Vliegenthart, and C.J. Corrigall-Brown. 2007. "Framing the 'French Riots': A Comparative Study of Frame Variation”, Social Forces, 86(2): 385-415.

Soroka, S.N. 2002. "Issue Attributes and Agenda-Setting by Media, the Public, and Policymakers in Canada”, International Journal of Public Opinion Research, 14(3), 264-285. 
Vliegenthart, R., D. Oegema and B. Klandermans. 2005. "Media Coverage and Organizational Support in the Dutch Environmental Movement”, Mobilization: An International Journal, 10(3), 347-361.

Voorhees, E. M. 2004. "Overview of the Trec 2001 Question Answering Track”. Proceedings of the Thirteenth Text REtreival Conference (TREC 2004).

Walgrave and Manssens

Walgrave, S. and J. Verhulst. 2003. "The February 15 Worldwide Protests against a War in Iraq: An Empirical Test of Transnational Opportunities. Outline of a Research Programme”. Paper presented at the International Workshop on Contemporary Anti-War Mobilizations, Agonistic Engagement Within Social Movement Networks, Corfu, Greece.

Walgrave, S. and J. Manssens. 2000. "The Making of the White March: The Mass Media as an Alternative to Movement Organizations”, Mobilization, 5(2), 217-239.

Walgrave, S. and J. Verhulst. 2005. “The 2003 Iraqi War : Politics, Media Coverage, Public Opinion, and Activists' Opinions in Eight Countries". Paper presented at the APSA preconference on Political Communication, Washington.

Weaver, D. H., and G.C. Wilhoit 1996. The American journalist: US News People at the End of an Era. Mahwah, NJ: Lawrence Erlbaum Associates.

\section{APPENDIX A LIST OF SEARCH-STRINGS}

1|CAF1|1\#|weapon* w/5 (mass destruction or chemic* or biologi* or nuclear*) or WMD or bioweapons or (smoking gun) or ((arms or bio* or

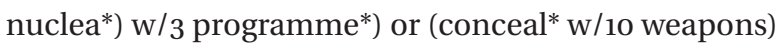

2|CAF2|1\#reasons w/10 war

$3|\mathrm{CAF} 3| \mathbf{1}$ (baghdad or saddam or hoessein or hussein) $\mathrm{w} / 10$ (al-q* or al $\mathrm{q}^{*}$ or bin or terror*)

${ }_{4}|\mathrm{CAF} 4|$ i\#oil w/10 (production or industr* or reserve) AND reason*

$5|\mathrm{CAN1}| 1 \#$ (threat or evidence) w/10 Iraq w/10 (exaggerat* or doubt* or $\left.\operatorname{sex}^{*}\right)$

$6|\mathrm{CAN} 2| 1 \#$ (unjust or lie or misleading or misled or mislead* or misguid* or undermin* or illegal or (arguing against)) w/10 (mass destruction or chemic* or biologi* or nuclear* or motivation or justification or (military action) or foreign policy) 
7|CAN3|1\#(abuse or incorrect*) w/10 (intelligence agenc* or FBI or CIA or MI5)

$8 \mid$ CAN4|1\#no weapons w/10 (find or found or no threat)

9|CAN5|1\#(refusal or veto) w/10 (France or Germany or Russia) or (political solution) or (international opposition)

10|CAN6|1\#absence w/5 (WMD or (weapons of mass destruction) or (biologi* or chemic* or nuclear*))

${ }_{11}|\mathrm{CAP} 1| \mathrm{1} \#$ threat $\mathrm{w} / 10$ Iraq $\mathrm{w} / 10$ (current or present)

${ }_{12}|\mathrm{CAP} 2| 1 \#$ (war or Blair or Bush) w/5 (correct or legitimi* or just or legal) ${ }_{13}\left|\mathrm{CAP}_{3}\right|$ 1\#protect* w/10 people w/10 (United States or US or American or UK or United Kingdom or English)

${ }_{14}|\mathrm{CAP} 4| \mathrm{1} \#$ ((cheat or retreat or violate or refusal) w/10 (UN or United Nations)) or (inspections w/10 pointless) or (material w/1 breach)

${ }_{15}|\mathrm{CAP} 5| \mathrm{1} \#(($ saddam or hoessein or hussein) w/10 (dictator or torture))* or (oppressive regime)

16|CAF5|1\#(father or history or (Bush w/1 (senior or sr*)) w/10 Bush ${ }_{17}|\mathrm{CAP} 7| 1 \#$ presence or (will be found) w/5 (WMD or (weapons of mass destruction) or (biologi* or chemic* or nuclear*)) 18|CAP8|1\#protect w/5 (isr* or region or middle-east)

$19|\mathrm{EFF} 1| 1 \#$ ((rebuild* or aftermath) w/10 iraq) or (stable w/5 government) or (postwar Iraq)

20|EFF2|1\#(economic or economy) w/5 (consequence* or effect*) 21|EFF3|1\#*prison* w/10 Guantanamo Bay

22|EFN1|1\#(death or suicide) w/5 Kelly 23|EFN2|1\#(postpone* or delay*) w/5 because w/10 war $24|E F N 3| 1 \#$ (no w/3 food) or (no w/3 money) or (anarchy) or (shortage w/3 water) or ((fight or fought) w/5 water) or ((pentagon or US or United States or American) w/10 colony) or (uncertain effect*) or plunder*

$25 \mid$ EFN4|1\# (country or iraq) w/20 ((torn or ruined or devastated or devastating or damage) or (grave* consequences) or (shortfall in funds) or (major crisis) or (risk w/5 hunger) or (potential catastrophe*) or (blam* w/5 (America* or US or United States or coalition)) or (lawless society) or (bitter faces) or (civilian anger))

26|EFN5|1\#((large or enormous or real) w/5 costs) or ((black hole) w/10 (fund* or finan*)) or (tax w/5 increase) or (spending w/3 cut*) or (ris* $\mathrm{w} / 10$ interest $\mathrm{w} / 10$ rate*) or (selling $\mathrm{w} / 5$ shares $\mathrm{w} / 5$ panic) or (stock w/1 market w/10 depress*) or (investors w/5 nervous) or (consumer* 
w/5 defer* w/5 purchase*) or ((fall or fell or decline) w/10 value w/10 (dollar or stocks or shares)) or (cooling w/5 euro) or ((rise or rock) $\mathrm{w} / 10$ (oil or petrol) w/10 price*) or (traumati* w/5 econom*) or (reduc* $^{*} / 5$ airline*) or ((have or has) w/5 fallen w/5 percent)

27|EFN6|1\#oil* w/10 (burn or fire)

28|EFN7|1\# ((transatlantic or trans-atlantic) w/10 relation* w/10 (detoriate* or affect* or damage*)) or ((US or United States) w/10 (Europe or EU or Europese Unie) w/10 relation w/10 (detoriate* or affect* or damage*))

29|EFN8|1\#refugee w/5 war

30|EFP1|1\#sign* w/5 progress

31|EFP2|1\#issue new banknotes

32|EFP3|1\#((liberate* or free) w/10 iraq w/10 (regime or dictator*)) or (regime change) or (cheering crowd) or (greatful w/5 (Iraqis or people)) or (democratic process*) or (iraq w/10 (prosperous or stable or peaceful or self-governing)) or ((liberation or democracy) w/5 people) $33|\mathrm{EFP} 4| 1 \#$ (good w/5 achieve*) or (command respect) or (victory w/5 fix) $34 \mid$ EFP $5 \mid 1 \#$ (child* w/5 school) or (health system w/5 (good or working or develop*))

$35 \mid$ EFP6|1\#(trigger w/10 economic $\mathrm{w} / 10$ revival) or (confidence $\mathrm{w} / 20$ econo* w/10 ris*) or (economic bounce) or (ris* w/5 (shares or stocks))

36|EFP7|1\#strong* w/10 (out of war)

37|PRN1|1\# (peace or anti-war or antiwar or (against w/5 war)) AND (activist* or demonstrat* or protest* or poem* or remark* or march* or rall* or stance)

38|PRN2|1\#pacifist*

$39|\mathrm{PRN} 3| \mathbf{1} \#$ (make love w/2 war) or (stop the war coalition) or (push for peace) or (chorus $\mathrm{w} / 2$ protest)

40|PRP1|1\#boycot* w/5 movie*

41|PRP2|1\#(pull for troops) or (pro-war w/5 (rall* or protest* or march* or demonstrat*)) or (rall*w/5 support w/5 (bush or troops)) or (bolstered w/5 support w/5 war) or (rall* w/5 for w/10 war)

42|REF1|1\#attack w/10 (devastating or bomb*)

43|REF2|1\# (air w/10 attack) or bombing or (anti-aircraft or antiaircraft) or (shock and awe) or (missile attack) or (drop w/5 bomb*) or (imminent attack) or (invasion) or (force* $\mathrm{w} / 5$ battl*) or gunfire or groundfire 
44|REF3|1\#(war w/10 inevitable) or (decision w/5 go w/5 war) or (buildup $\mathrm{w} / 5$ war) or (prospect w/5 war) or (military action)

${ }_{45} \mid \mathrm{REN1} 1 \mathrm{1}$ ((slaughter* or wound* or kill* or murder* or assassinat* or (lost w/5 live) or dead* or injured) w/10 (coalition or US or American or English or UK or Spanish or Italian) w/10 (troops or soldier* or civilian* or marin*)) or (sacrific* w/5 war) or (guerilla w/10 (war or tactic $\left.^{*}\right)$ )

46|REN2|1\#(worst week for US soldiers)

47|REN3|1\#friendly fire or (coming under fire) or (collateral damage)

$48\left|\mathrm{REN}_{4}\right| \mathrm{i} \#$ (arrogant or imperial) w/5 (power or unilateral*)

49|REN5|1\#(obstruct or diplomacy*) w/5 (war or attack)

50|REN6|1\#suicide w/5 (attack or bomb)

51|REP1|1\#death or capture AND (uday or qusay or ali)

52|REP2|1\#(America* or United States or US or coalition or UK or United

Kingdom or English*) w/10 ((taking control) or (progress) or advances or racing or (statue* ${ }^{*} / 5$ fall*))

Note:

CAF = legitimization-neutral; CAN = legitimatization-negative; CAP = legitimization-positive; $\mathrm{EFF}$ = consequences-neutral; $\mathrm{EFN}$ = consequences-negative; $\mathrm{EFP}=$ consequences-positive; REF = intervention-neutral; $R E N$ = intervention-negative; $\mathrm{REP}=$ intervention-positive; $\mathrm{PRN}=$ protest-negative; $\mathrm{PRP}=$ protest-positive; $\mathrm{w} / \mathrm{x}=$ within $\mathrm{x}$ words'; ${ }^{*}=$ any character(s) 


\section{English Abstracts}

Framing the Iraq War

A Cross-National Comparison

of Newspaper Framing in

Four Western Countries

\section{RENS VLIEGENTHART \& HEIKE SCHRÖDER}

In this paper we compare the newspaper attention for and framing of the Iraq issue in four Western countries (US, UK, Germany and the Netherlands) during the period September 2002 until August 2003. Using computer assisted coding based on wordlists constructed by human coders, we analyzed more than 70,000 articles from 12 newspapers. We pose the question how framing differs across countries, time and newspapers. Our results confirm the vast majority of our hypotheses and demonstrate that the national political context, the political leaning of newspapers and the stage of the conflict can account for a large amount of the variation in the attention for the issue and in the way it is presented. 